\title{
Water level modulation of current vectors and sediment flux in a transverse bar-rip cell
}

\author{
B. Greenwood ${ }^{1}$, R. W. Brander ${ }^{2}$, B. Perez ${ }^{3}$, E. Joseph ${ }^{2}$ \& J. Z. Li ${ }^{1}$ \\ ${ }^{1}$ Department of Physical and Environmental Sciences, \\ University of Toronto Scarborough, Toronto, Canada \\ ${ }^{2}$ School of Biological, Earth and Environmental Sciences, \\ University of New South Wales, Australia \\ ${ }^{3}$ Department of Geology, University of Toronto, Canada
}

\begin{abstract}
Measurements of mean water level and surface waves (Druck 1830 piezoresistive transducers and Plexiglas ${ }^{\mathrm{TM}}$ stilling wells), shore-parallel and shorenormal currents (Marsh-McBirney OEM512 electromagnetic current meters), and suspended sediment concentrations (D\&A Instruments OBS1P and OBS3 optical backscatter sensors) were recorded continuously at $4 \mathrm{~Hz}$ within a microtidal transverse bar-rip cell at Bennett's Beach, NSW, Australia. Currents (at elevations of $\mathrm{z}=0.13,0.39,0.50 \mathrm{~m}$ ) and sediment concentrations (at $\mathrm{z}=0.13$, $0.26,0.39 \mathrm{~m}$ ) were recorded under low to moderate swell during spring tides at three key locations: (a) transverse bar crest; (b) rip feeder current channel; (c) rip channel neck. Current roses illustrated the rip cell flow patterns (8-minute records every 15 minutes) over the tidal cycle. Velocity vectors in the rip neck revealed: (i) maxima $\left(1.50-1.75 \mathrm{~m} \mathrm{~s}^{-1}\right)$ at high water and minima at low water in contrast with other data for bathymetrically constrained rips; (ii) directionally well-constrained, but highly unsteady, currents. Currents in the feeder channel were: (i) the most variable in terms of speed and direction, with an angular spread of $>200^{\circ}$; (ii) actually opposed to the mean flow in some cases; this reflects either extreme meandering or more likely the presence of large-scale vorticity superimposed on the mean flow, similar to the large Lagrangian structures detected by others. Breaking waves on the bar crest produced flow vectors reflecting: (i) a strong longshore current; (ii) an onshore mass transport; (iii) a distinct undertow. Vector variability was the major influence on the timeaveraged mean suspended sediment transport within the rip neck.

Keywords: tidal phase, rip cell circulation, current and sediment flux vectors.
\end{abstract}




\section{Introduction}

In both marine and lacustrine environments, intermediate transverse bar-rip (TBR) systems (Wright and Short [1]) are characterized by strong mean flows (rip current systems) as an integral part of a cellular water and sediment circulation leading to morphodynamic adjustments. The "classic" model is one of a net flux of water landward across the bar under breaking waves, followed by an alongshore and seaward flux through the feeder channel and rip neck (Sonu [2]; Komar [3]). "Rips" are defined as narrow, topographicallyconstrained, "quasi-steady" flows directed offshore through the breaker zone as "jets", forced by the alongshore variable radiation stress and water level set-up induced by incident gravity waves breaking on the segmented nearshore bar. Current speeds, which may reach up to $2 \mathrm{~m} \mathrm{~s}^{-1}$, are not, however, remotely "quasi-steady", but instead are modulated at a wide range of frequencies, often lower than those of the incident gravity waves which force the current system. Furthermore, the flux of water and sediment is affected by the water level in the cell, and especially tidal levels, even under micro-tidal conditions (Aagaard et al. [4]; Brander [5]; MacMahan et al. [6, 7]). However, detailed measurements of mean water levels both outside and within a rip cell are limited and the tidal effect, relative to other constraints on the hydrodynamics, has not been studied in detail. Recent field and numerical experiments show that many cellular flows involve closed vortical systems inside the surf zone, and only occasionally do rips expel water offshore. It has been suggested that these "pulses" of offshore flow are the main mechanism for water (and possibly sediment) exchange between the surf zone and the inner nearshore (e.g. MacMahan et al. [8]; Bruneau et al. [9]). Greenwood et al. [10] demonstrated that low frequency motions (infragravity and far infragravity oscillations) can influence the transport of suspended sediment, at least in the rip neck, and may control the direction of the net flux. However, the nature of currents within a rip cell and the role they play in transporting sediment is virtually unknown, since measurements of sediment flux are extremely limited. This paper examines flow and suspended sediment transport vectors at a number of elevations and locations within a transverse bar rip system; these are related to the tidal water levels. The aims are to better understand rip cell hydrodynamics, the associated sediment suspension and transport, and especially the role played by tidally driven water levels.

\section{Location and methods}

\subsection{Study site}

Mean water levels, waves and horizontal currents were recorded over several days in February, 2004 during the falling stage, through the low water stage and the subsequent rising stage of a spring tide in a single asymmetrical cellular rip system. The latter forms part of a large "intermediate transverse bar-rip" morphological configuration at Bennett's Beach, NSW, Australia (Wright and Short [1]; Fig. 1); for greater detail on the field site, see Greenwood et al. [11]). 


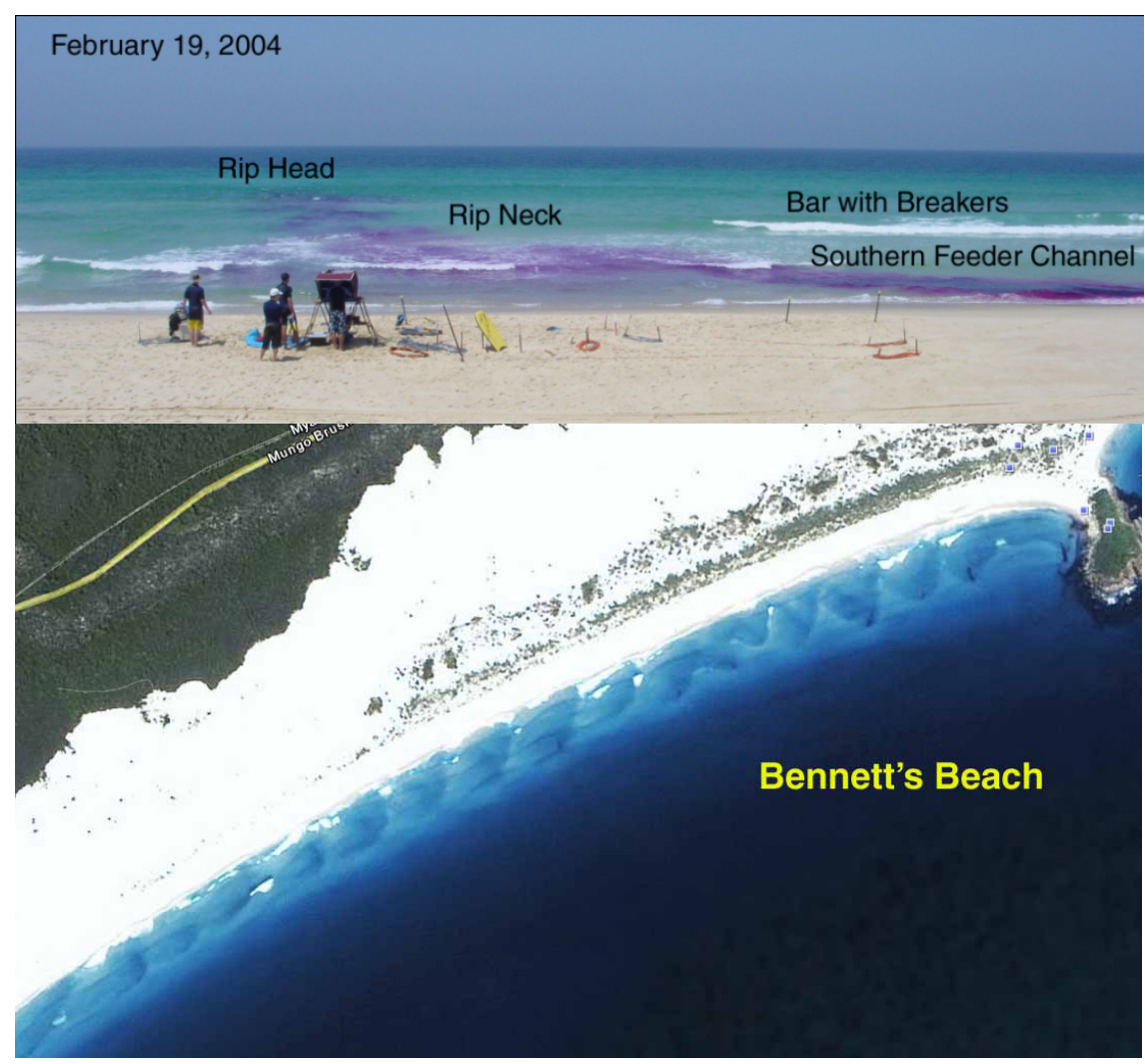

Figure 1: Tracer deployment in the study rip cell (upper panel) on February $19^{\text {th }}, 2004$, and a Google view of the intermediate transverse bar-rip system, Bennett's Beach, Hawks Nest, NSW, Australia (lower panel).

The beach experiences a micro-tidal, mixed semi-diurnal regime and measurements were taken during a period of spring tides. The beach is oriented to a SSE exposure and was subject to long period swell from the Tasman Sea during the study period coupled with a variable wind-wave field, forced by a daily sea breeze. The rip cell was slightly asymmetric, with a dominant feeder current flowing from the southwest towards the north-east. The bathymetry of the rip system is shown in Figure 2 together with the measurement locations. A dominant, oblique nearshore bar was welded to a shoal to the south and extended alongshore in a north-easterly direction to end at the neck of a rip channel; a trough separated the bar from the beach face, varying in depth from near zero where the bar was welded to the shoal, to $\sim 1 \mathrm{~m}$ deep before it turned offshore into the rip neck. At high tide the neck was $\sim 1.75 \mathrm{~m}$ deep. Over the 3-day monitoring period, the transverse bar prograded $\mathrm{NE}$ and moved offshore forcing the rip neck to migrate also, with a constriction and increase in depth (Fig. 2). 

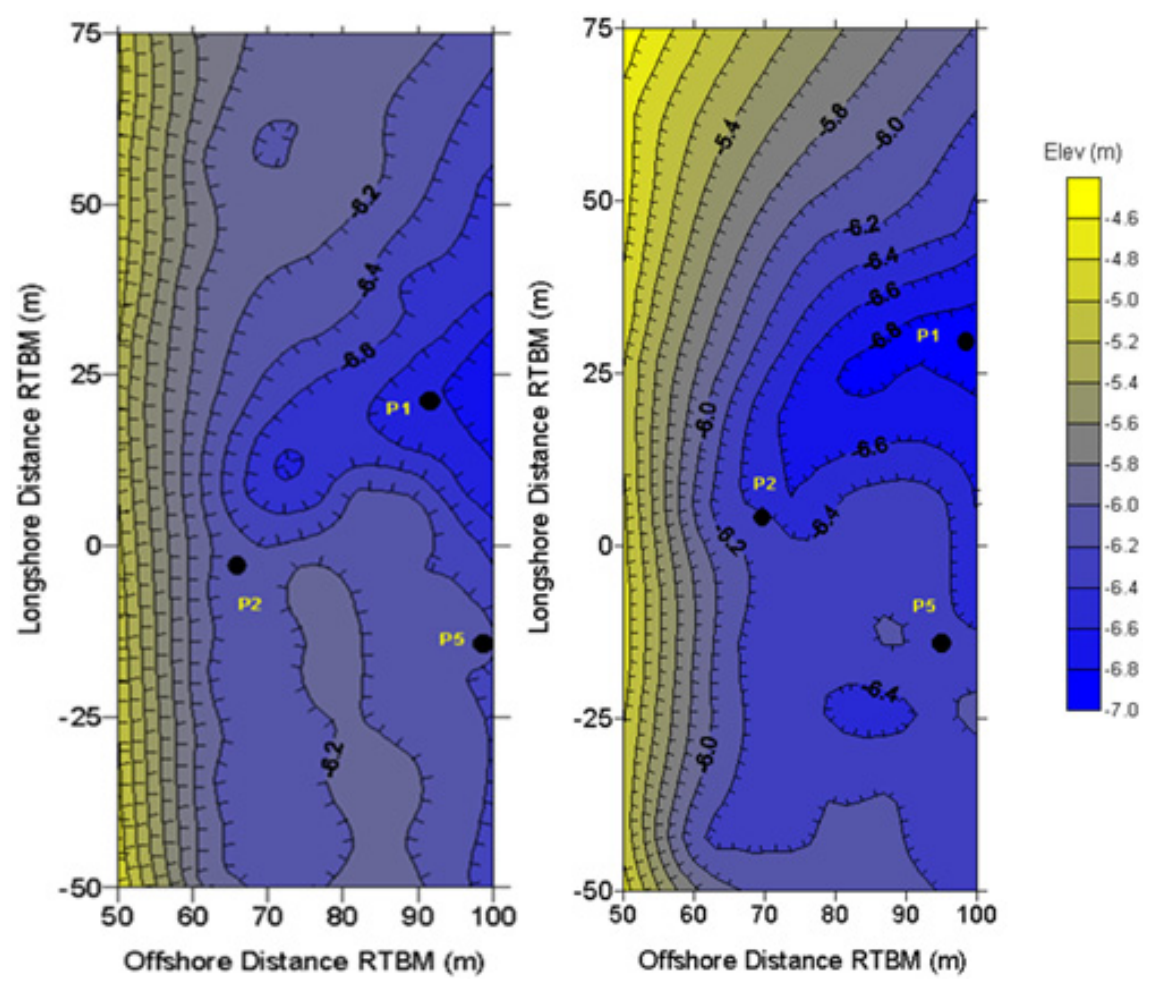

Figure 2: $\quad$ Nearshore bathymetry, Bennett's Beach, February $19^{\text {th }}$ (left panel) and $21^{\text {st }}$ (right panel). P1 marks the instrument pod in the rip neck and P2 and P5 mark the pods in the feeder channel and on the bar crest. Note: RTBM is relative to a bench mark behind the subaerial beach.

\subsection{Measurements}

Instruments were deployed each day (Fig. 2) near high tide in the centre of the rip neck (P1), in the feeder channel (P2) and on the bar crest (P5) to record: (a) cross-shore and alongshore (relative to the average local shoreline orientation) horizontal currents, at elevations of $0.13,0.39,0.50 \mathrm{~m}$, using biaxial electromagnetic current meters (Marsh-McBirney, OEM 512); (b) sediment concentrations at $0.13,0.26,0.39 \mathrm{~m}$, using optical backscatter sensors (D\&A Instruments, OBS-1P and OBS-3); (c) mean water surface elevations and waves, using strain-gauge pressure sensors (Druck-1830); (d) mean water surface elevations were also determined using stilling wells located along the length of the feeder channel. These consisted of $1.5 \mathrm{~m}$ long, $0.10 \mathrm{~m}$ diameter Plexiglas ${ }^{\mathrm{TM}}$ tubes with 2 pin holes at the base, mounted on "star pickets" driven vertically into the bed; fluorocene was added to assist in identifying the water level. Waves incident to the surf zone were recorded by a pressure sensor deployed $\sim 130 \mathrm{~m}$ 
directly offshore of the bar (station P3); this sensor also recorded the ocean tide. Data from the electronic sensors were recorded continuously at $4 \mathrm{~Hz}$, but stored for convenience in consecutive blocks of 4096 data points ( 17-minute "bursts").

\subsection{Analysis}

Time series of the two horizontal components of the instantaneous fluid velocity and the suspended sediment concentration were used to compute the instantaneous current and sediment transport vectors. Concentrations measured at 0.13 and $0.26 \mathrm{~m}$ were both coupled with velocities measured at $0.13 \mathrm{~m}$; concentrations measured at $\mathrm{z}=0.39 \mathrm{~m}$ were coupled with velocities measured at $\mathrm{z}=0.39 \mathrm{~m}$. There is potential error here (see Austin and Masselink [12]); however, in all cases the measured currents at $0.13 \mathrm{~m}$ were only very slightly different from those measured at 0.39 and $0.50 \mathrm{~m}$; the latter two were essentially identical. The sensors were supported on a solid heavy base, which did not allow significant shifts in elevation once the support settled. The current and sediment transport vectors were computed using a 16-point compass and rotated so that north became the average shoreline orientation and plotted using WindRose PRO3 supplied by Enviroware ${ }^{\mathrm{TM}}$, a Windows application for analysing and plotting directional variables.

\section{Tidal constraints on Rip circulation at Bennett's Beach}

According to Short and Woodruffe [13], Australia's east coast tides are forced by one dominant amphidromic system, the Southwest Pacific Tidal System, with its centre located to the south-east of New Zealand. However, as with most tides around the world the range and phase of the tide at any coastal location is complex and can only be determined empirically using long records of water levels referenced to some datum. Data obtained from the Manly Hydraulics Laboratory (Public Works, NSW, Australia) provided tidal water levels for the Tomaree Tidal Station in the Port Stephens ria-estuary, located at the southern end of Bennett's Beach.

\subsection{Mean current speed in the rip neck and tidal levels}

In 2009, Greenwood, et al. [11] showed that contrary to the accepted literature, the time-averaged offshore component of the current directed through a topographically constrained rip channel neck on Bennett's Beach actually decreased as tidal levels fell, when the speed was averaged over $\sim 17$ minutes (i.e. 4096 data points recorded at $4 \mathrm{~Hz}$ ). To examine flow within the rip cell in greater detail, the current and sediment concentration data were re-organized to: (i) compute the instantaneous vectors at each location within the cell, and (ii) construct current and suspended sediment transport roses equivalent to each 15-minute water level recorded (i.e. at Tomaree and stations P1, P2, P3, P5). In this way it was hoped that a firm relationship could be established between the tidal water levels, rip cell circulation and suspended sediment flux by the mean currents. 
The Tomaree gauge provides continuous records of the average water level every 15 minutes throughout each day starting at midnight (K. Alley, MHL, pers. comm. Oct., 2011). It does this by averaging measurements at 1 -second intervals for a 2-minute period (1-minute each side of each 15-minute time stamp) for a total of 96 readings per day. In order to determine "equivalent" mean water levels recorded by the pressure sensors deployed at Bennett's Beach, a number of steps were taken: (a) Tomaree time stamps were corrected to Daylight Saving Time, since DST was used for the experimental data; (b) since the pressure sensors at Bennett's Beach were "polluted" by waves, the number of data points averaged around the "equivalent" 15-minute time stamp were larger for the experimental data than the Tomaree records. To obtain a "good mean" water level from the pressure sensors, a total of 960 discrete water surface elevation values (equivalent to 4-minutes of record at $4 \mathrm{~Hz}$ ) were averaged each side of the 15-minute time stamp for a total of 8 minutes of record. (c) all mean water levels were also normalized with respect to the maximum level in that time period and plotted against time. (d) a non-linear regression model was fitted to each time series; these non-linear models, which explained upwards of $98 \%$ of the variance, were then used for further analysis. Specifically, the time of the lowest water level for each station was computed by taking the derivative of the non-linear function, and determining the location in time of the function minimum.

Figure 3 illustrates the absolute and normalized the water level curves for the tidal cycle on February $19^{\text {th }}$ at Tomaree and stations P3 and P1 at Bennett's Beach. Also shown are the computed times of the lowest water level (tide). Two aspects are apparent: (i) the range of normalized water levels is a minimum at station (P3), a maximum at Tomaree within a topographically restricted inlet, and the range in the rip neck is intermediate between these two; (ii) there are distinct differences in the time of low water reached at each of the station. Low water arrives first offshore of Bennett's Beach (station P3) at $1507 \mathrm{~h}$, while it does not arrive until $1536 \mathrm{~h}$ at Tomaree. (iv) surprisingly, there is also a lag of $\sim 30$ minutes between low water in the rip neck (station P1) and low water at station P3.

\subsection{Current vectors within the rip cell}

Rip neck: The time-averaged current in the rip channel neck reached its maximum at the highest tidal water level recorded at station P3 (1230-1245 h; Greenwood et al. [11]). At this time the flow vectors were well-constrained directionally, even in the presence of waves propagating onshore, although, there was some variability with elevation. Figure 4 illustrates current roses at $\mathrm{z}=0.13$, 0.39 and $0.50 \mathrm{~m}$ at station $\mathrm{P} 1$; maximum speeds reached $1.50-1.75 \mathrm{~m} \mathrm{~s}^{-1}$. At $0.13 \mathrm{~m}$, flows were dominated by $\mathrm{E}$ and ENE currents, accounting for $\sim 60 \%$ of the vector distribution; at 0.39 and $0.50 \mathrm{~m}$, there was a similarly narrow directional distribution. However, now the dominant vector had shifted to the $\mathrm{E}$, with a secondary vector to the ESE. There was a rotation of the flow towards the ESE from E. Two possibilities may account for this: (a) south-easterly swell refracting into the rip channel; waves have a greater influence with increasing 

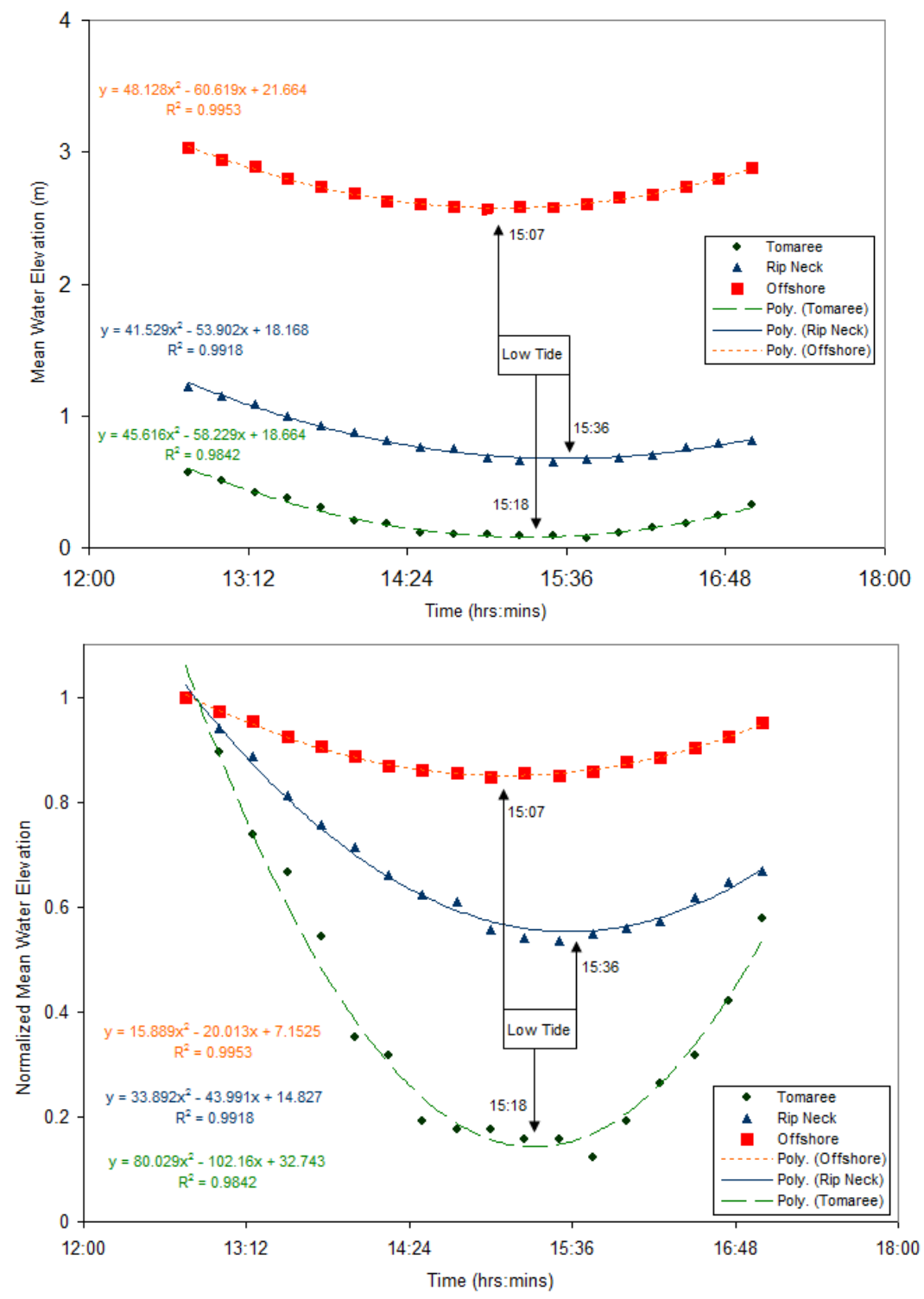

Figure 3: Absolute (upper panel) and normalized (lower panel) mean water levels recorded at: Tomaree, station P3 offshore, and in the rip neck, station P1. Non-linear, least squares regressions are fitted to the water levels and the times of low tide are those predicted by the regressions; associated $\mathrm{R}^{2}$ values show that upwards of $98 \%$ of the variance is explained. Note: Tomaree water levels are relative to the Australian datum; Bennett's Beach water levels are absolute water depths. 

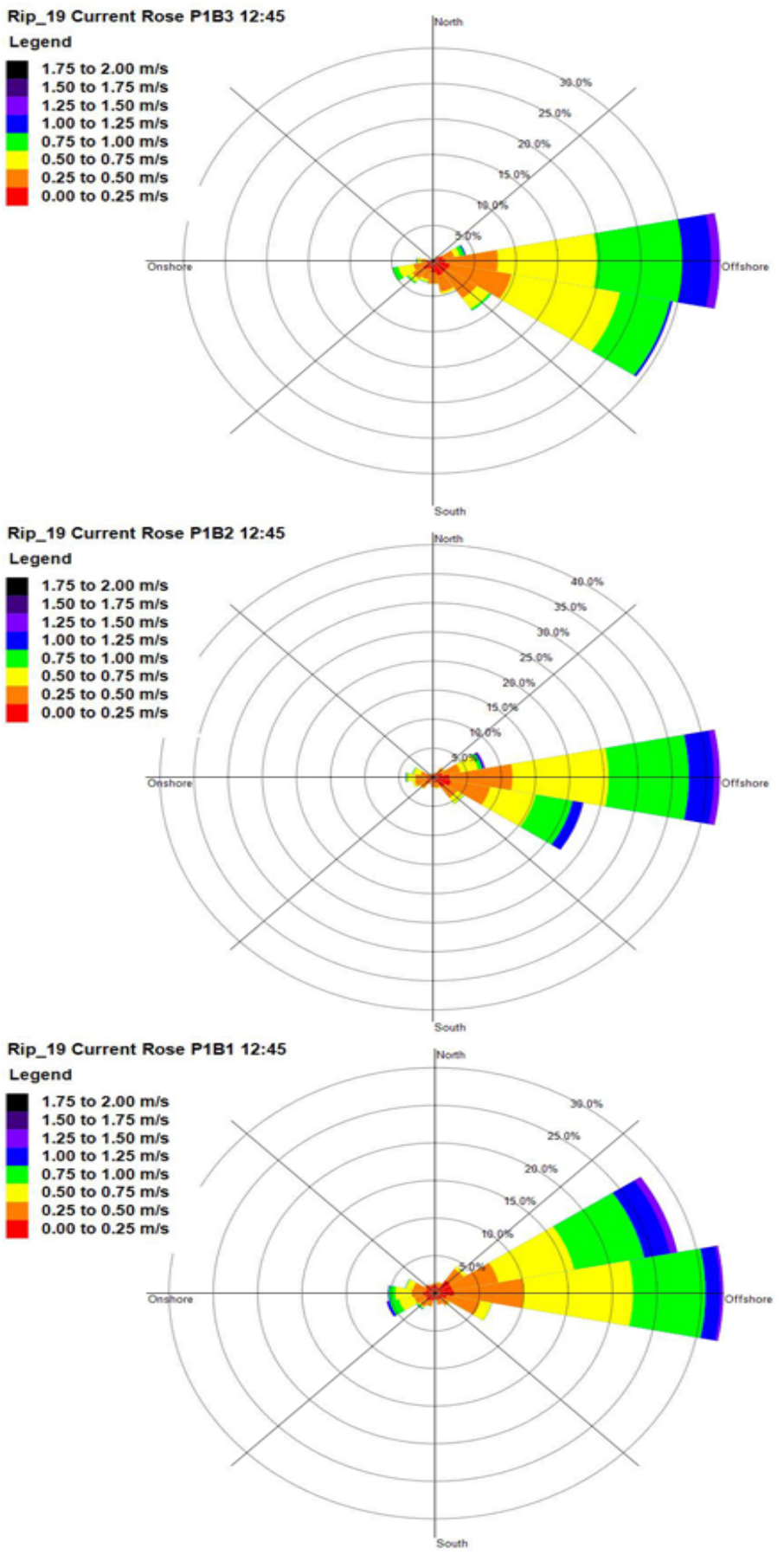

Figure 4: Current roses: rip neck at $1245 \mathrm{~h}$ at $\mathrm{z}=0.13,0.39$ and $0.50 \mathrm{~m}$. 
elevation away from the bed. (b) a small secondary flow from the NW in this asymmetrical rip cell. Regardless, the currents at all elevations followed the general channel orientation closely. Although gravity waves were propagating onshore at this time, the expected onshore component of motion was small $(5 \%$ or less of the total vectors were directed onshore). At this time of high water the rip current clearly overwhelmed any wave motion or secondary feeder current. At low water at P3 (1507 h), the current distribution in the rip neck was significantly different (Fig. 5): (a) there was an increase in the spread of the direction of the current; while the ENE direction was still dominant, the percentage of ENE vectors dropped to near $30 \%$ from $40 \%$, and a significant amount of the flow was directed to the NE (15-20\%) and even to the NNE and $\mathrm{N}$. (b) although the number of vectors reaching speeds $>1.0 \mathrm{~m} \mathrm{~s}^{-1}$ were significantly reduced they were still directed to the ENE and NE. However, the percentage of the vector distribution with speeds $<0.5 \mathrm{~m} \mathrm{~s}^{-1}$ was now much larger $(>10 \%)$, accounting for the reduction in the mean current. The flow pattern at low water was that of a meandering rip flow of lower velocity. As the tide rose to high water $(1715 \mathrm{~h})$ the directional spread of the rip current was probably the greatest of any period, with significant flow components $(>10 \%)$ directed from the NNE through to the ENE, with currents exceeding $0.75 \mathrm{~m} \mathrm{~s}^{-1}$ in all these directions.

Feeder channel: Perhaps the most significant characteristic of the current vector distribution within the feeder channel throughout the tidal cycle was its directional variability. At all time stamps from 1230-1700 h, the current direction varied from SW to ESE, an angular variation of 225 degrees, although distributions were not identical throughout this time interval. At high water stage $(1230 \mathrm{~h}, 1245 \mathrm{~h}$ and $1300 \mathrm{~h})$, when the current through the rip neck reached a maximum, the current vectors were dominated by flows to the ENE or NE (Fig. 6), reflecting flow accelerating into the rip itself. At low water (1500 h) there was a distinct shift in current direction with the dominant direction of flow now directed to the $\mathrm{N}$ ( $\sim 20 \%$ of vectors). At this time there was no evidence for any flows in a southerly direction. As the tide rose once more and the rip current reached another maximum $(1700 \mathrm{~h})$, the pattern of vectors in the feeder channel indicated an increase in the speed of flow, with higher percentages of currents $>0.5 \mathrm{~m} \mathrm{~s}^{-1}$, and a rather narrower directional spread.

Bar crest: Unfortunately, of the current sensors on the bar crest, only the lowermost sensor could be used, because the sensors at higher elevations were intermittently exposed during breaking waves. Nevertheless, at high water (1230 h), when the mean current in the rip neck reached its maximum, the current vectors on the bar crest at $\mathrm{z}=0.13 \mathrm{~m}$ were fairly well constrained (Fig. 7), even in the presence of breaking waves. The two primary vectors were directed to the ENE $(>20 \%)$ and E ( $>15 \%)$; thus near the bed, the dominant flow was directed offshore against the oncoming waves. Maximum velocities $\left(>1.0 \mathrm{~m} \mathrm{~s}^{-1}\right)$ were also associated with $\mathrm{E}$ and ENE flows. This offshore flow was undoubtedly due to the presence of an undertow in the presence of breaking waves, which in combination with the seaward surge of the incident gravity waves led to this pattern. It is clear from Figure 7 that at this time there was little evidence for 

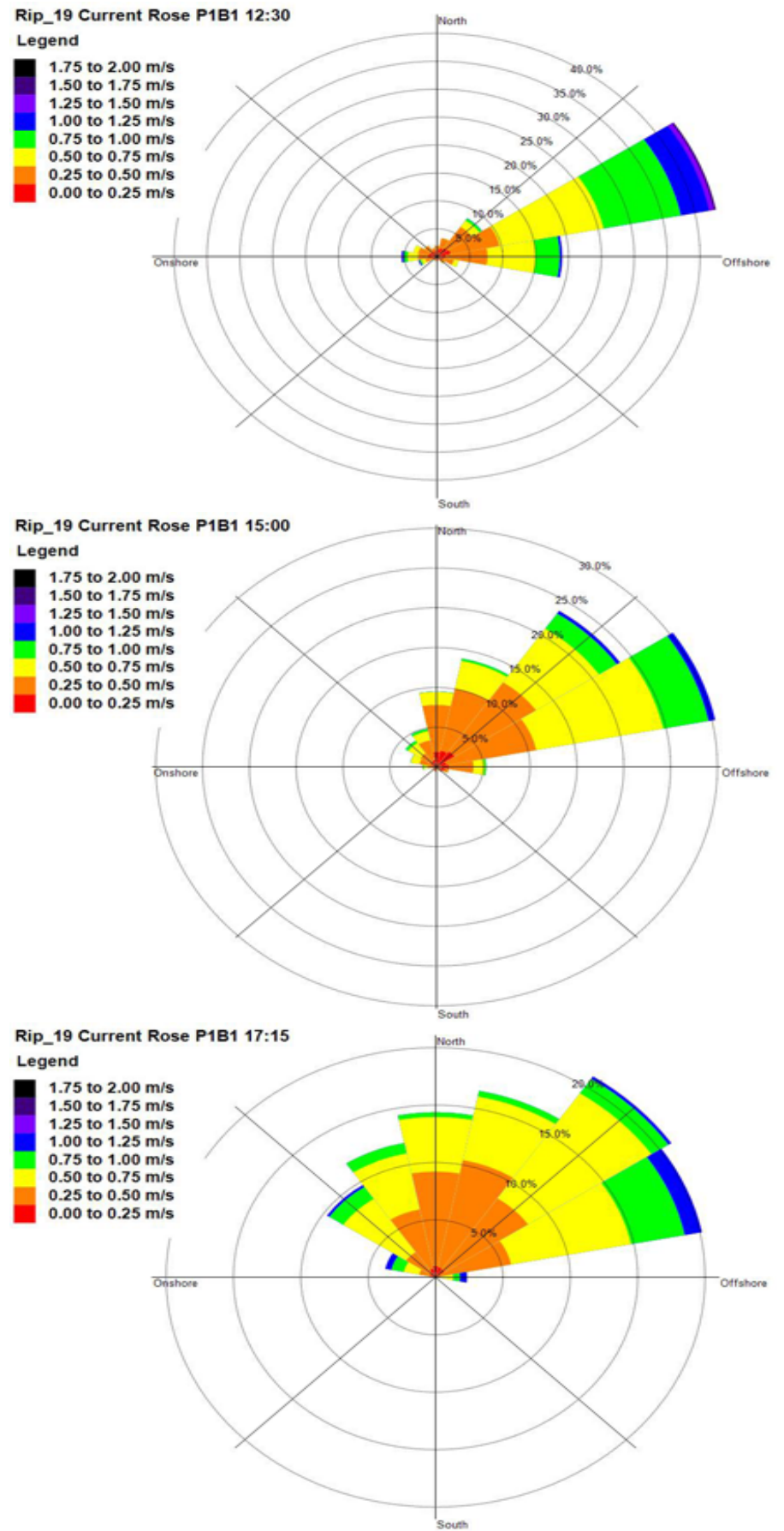

Figure 5: Current roses: rip neck at $\mathrm{z}=0.13 \mathrm{~m}$ at different tidal stages. 

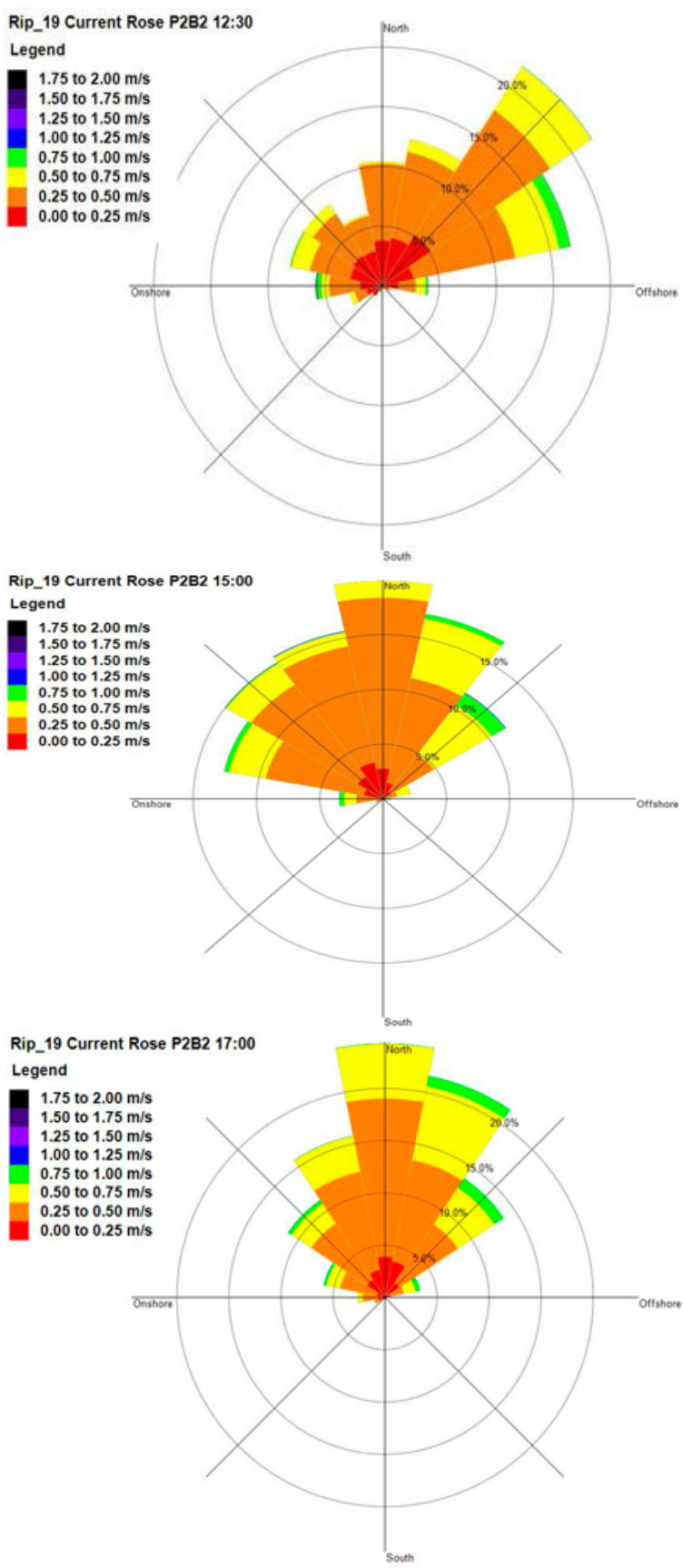

Figure 6: Current roses: feeder channel at $\mathrm{z}=0.39 \mathrm{~m}$ at different tidal stages. 

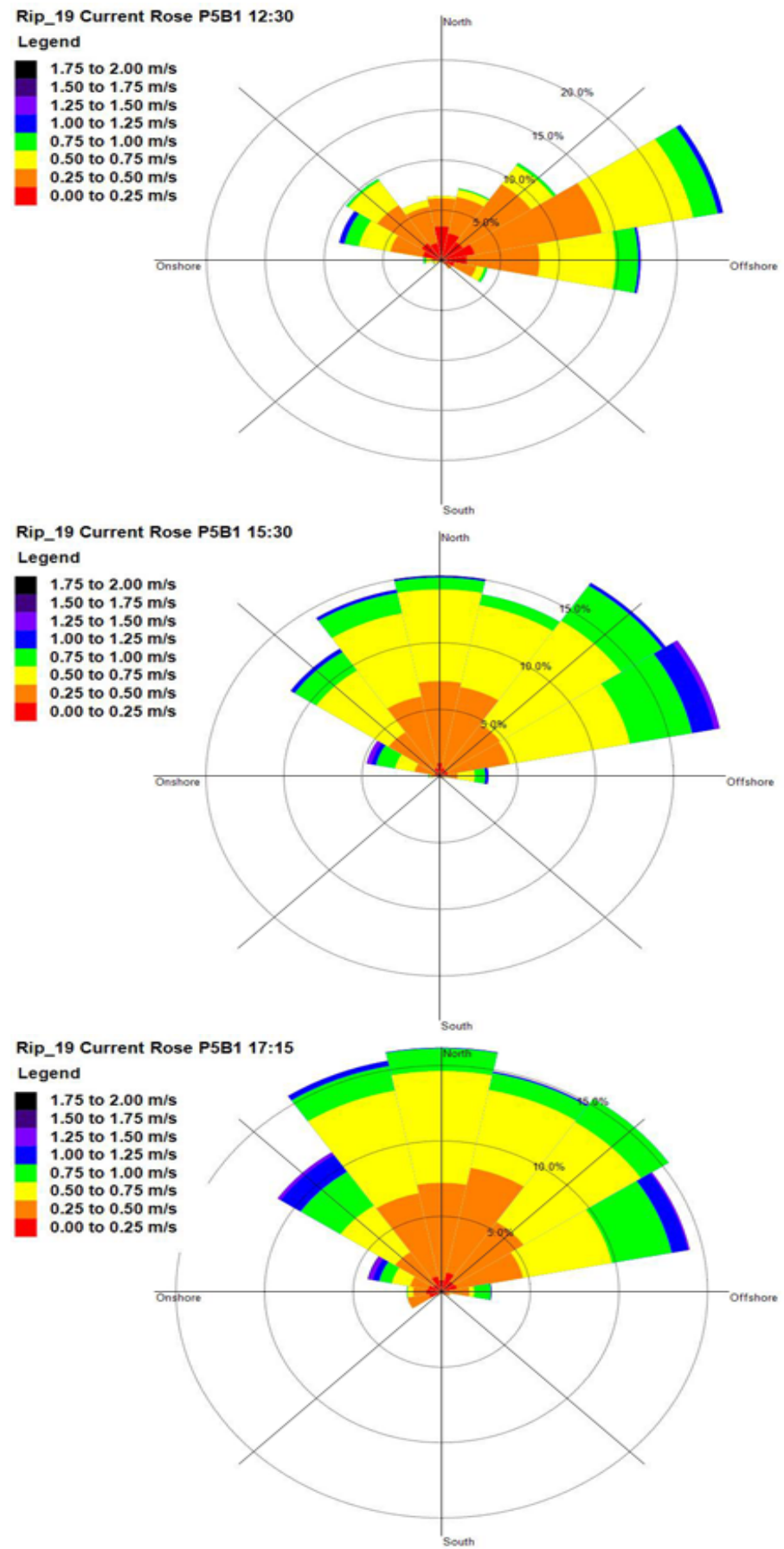

Figure 7: Current roses: bar crest at $\mathrm{z}=0.13 \mathrm{~m}$ at different tidal stages. 
strong or even relatively steady longshore current oriented parallel to the bar crest. However, by $1530 \mathrm{~h}$, the near-bed vectors became more evenly distributed from ENE through to NNW, and strong currents $\left(>1.0 \mathrm{~m} \mathrm{~s}^{-1}\right)$ were directed along the bar crest. As water level rose again to a maximum $(1715 \mathrm{~h})$, the flow pattern at P5 did not change significantly; it was still dominated by the combination of and offshore directed undertow, shore-parallel longshore currents and significant wave driven components to the WNW and NW.

\section{Suspended sediment flux in the rip neck}

In this short paper, it is only possible to examine suspended sediment transport vectors at one location. The rip neck will be used as it is the location where most of the sediment exits the rip cell. Figure 8 illustrates the near bed $(\mathrm{z}=0.13 \mathrm{~m})$ sediment flux vectors at two high water stages and at low tide. As expected the transport vectors were as well constrained directionally as were the currents. At high water $(1230 \mathrm{~h}),>40 \%$ of the transport was directed ENE. The only other significant vectors were directed to the $E(>15 \%)$ and rather surprisingly to the $\mathrm{W}(>5 \%)$. Instantaneous transport rates reached $>7.75 \mathrm{~kg} \mathrm{~m}^{-2} \mathrm{~s}^{-1}$ towards the ENE; however the majority of the transport rates were $<2.50 \mathrm{~kg} \mathrm{~m}^{-2} \mathrm{~s}^{-1}$. Thus, the magnitude of transport, while well-directed, was extremely variable, much more than would be expected in a quasi-steady flow. This undoubtedly reflects the highly episodic nature of suspension by a quasi-steady current in the presence of progressive gravity waves (see Greenwood et al. [11]). Near low water (1500 h; Fig. 8), transport rates dropped as expected; however, even with rising water levels and an increase in the time-averaged current, the current rose was very similar to that recorded at low water.

\section{Conclusions}

Analysis of current and suspended sediment transport vector distributions from a number of locations in a transverse bar rip cell illustrated the following:

- Velocity vectors in the rip neck revealed: (i) maxima $\left(1.50-1.75 \mathrm{~m} \mathrm{~s}^{-1}\right.$ ) at high water and minima at low water contrasting with other data for bathymetrically constrained rips; (ii) vectors were directionally wellconstrained, but speeds were highly unsteady.

- Currents in the feeder channel were: (i) the most variable in terms of speed and direction, with an angular spread of $>200^{\circ}$; (ii) in some cases, actually opposed to the mean flow; this reflects either extreme meandering, or more likely the presence of large-scale vorticity superimposed on the mean flow, similar to the large Lagrangian structures detected by other authors.

- Breaking waves on the bar crest produced flow vectors reflecting: (i) a strong longshore current; (ii) an onshore mass transport current; (iii) a distinct undertow directed offshore.

- Vector variability was the major influence on the time-averaged mean suspended sediment transport within the rip neck. 

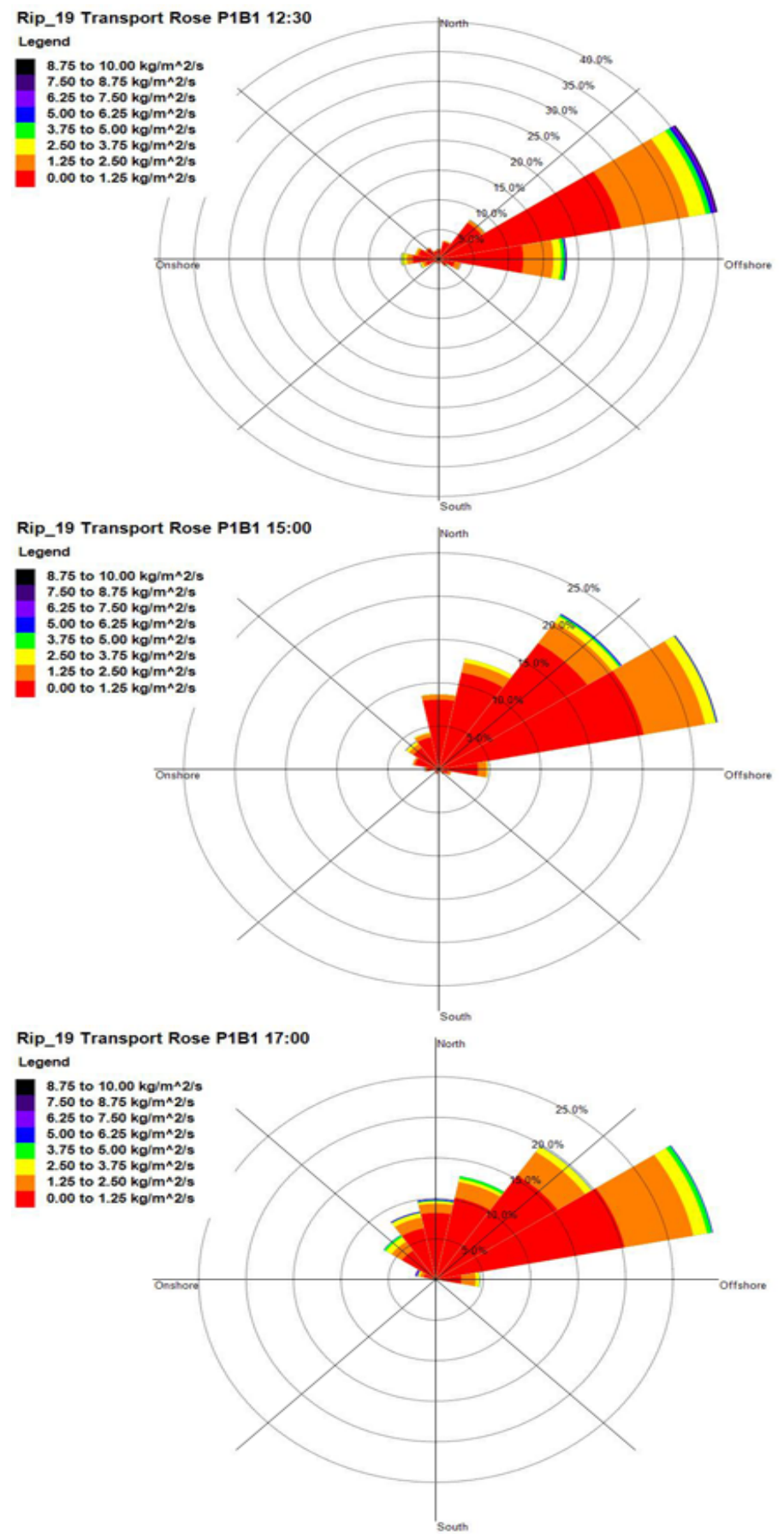

Figure 8: $\quad$ Transport roses: rip neck at $\mathrm{z}=0.13 \mathrm{~m}$ at different tidal stages. 


\section{Acknowledgements}

Funding was provided by NSERC Canada (BG) and a University of New South Wales FRGP grant (RWB). Jing Zhi Li was supported by a University of Toronto Research Completion Award. Drs T. Baldock (Queensland), M. Hughes, F. Weir and undergraduate M. Daly (Sydney) provided valuable field assistance; Dave Mitchell (Sydney) provided technical, field and culinary skills. Ms Linda Do, Ms Kristy Alley and Mr Rob Jacobs (Manley Hydraulics Laboratory) are thanked for their assistance with tidal data.

\section{References}

[1] Wright, L.D., Short, A.D. Morphodynamic variability of surf zones and beaches: a synthesis. Marine Geol., 56: 93-118, 1984.

[2] Sonu, C. Field observations of nearshore circulation and meandering currents, Journal Geophys. Res., 77, 3232-3247, 1972.

[3] Komar, P.D. Beach Processes and Sedimentation. 2nd Edition, Prentice Hall, New Jersey, p. 338, 1998.

[4] Aagaard, T., Greenwood, B., Nielsen, J. Mean currents and sediment transport in a rip channel. Marine Geol., 140: 25-45, 1997.

[5] Brander, R.W. Field observations on the morphodynamic evolution of lowenergy rip systems. Marine Geol., 157: 199-217, 1999.

[6] MacMahan, J.H., Thornton, E.B., Stanton, T.P., Reniers, A.J.H.M. RIPEX: observations of a rip current system. Marine Geol., 218: 113-134, 2005.

[7] MacMahan, J.H., Thornton, E.B., Reniers, A.J.H.M. Rip Current Review. Coastal Eng., 53: 191-208, 2006.

[8] MacMahan, J.H., Reniers, Ad J.H.M., Thornton, E.B. and Stanton, T.P. Infragravity rip current pulsations. Journal Geophys. Res., 109: C01033-, 2004.

[9] Bruneau, N., Castelle, B., Bonneton, P. and Pedreros, R. Very low frequency motions of a rip current system: observations and modeling. Journal of Coastal Research, SI 56: 1731-1735, 2009.

[10] Greenwood, B., Brander, R.W., Joseph, R. Far-infragravity \& infragravity "pulses" in a rip current. In: Coastal Processes II, edited by C.A. Brebbia, G. Benassai and G.R. Rodriguez, WIT Press, p. 123-135, 2011.

[11] Greenwood, B., Brander, R.W., Joseph, R., Hughes, M.G., Baldock, T. and Aagaard, T. Sediment flux in a rip channel on a barred intermediate beach under low wave energy. In: Coastal Processes, edited by C.A. Brebbia, G. Benassai and G.R. Rodriguez, WIT Press, p.197-209, 2009.

[12] Austin, M.J., Masselink, G. The effect of bedform dynamics on computing suspended sediment fluxes using optical backscatter sensors and current meters. Coastal Eng. 55: 251-260, 2008.

[13] Short, A.D., Woodruffe, C.D. The Coast of Australia. Cambridge University Press, Cambridge, 299 pp. 2009. 